\title{
Hypothyroidism and Non-Alcoholic Fatty Liver Disease: Association and Effect of Levothyroxine Replacement Therapy
}

Mokhtar M. Shatla ${ }^{1,2 *}$, Ahmed S. Faisal ${ }^{3}$

${ }^{1}$ Department of Family Medicine, Menoufia Faculty of Medicine, Menoufia University, Shebin Alkom, Egypt.

${ }^{2}$ Department of Family Medicine, Umm Alqura Faculty of Medicine, Umm Alqura University, Makkah, Saudi Arabia. ${ }^{3}$ Department of Infectious Diseases, Suez Canal Faculty of Medicine, Suez Canal University, Ismailia, Egypt, and Department of Infectious Diseases, Umm Alqura Medical Center, Umm Alqura University, Makkah, Saudi Arabia.

Abstract:
Background: The association between hypothyroidism and non-alcoholic fatty liver disease (NAFLD)
is increasingly studied with controversial results, and evidence regarding the effect of levothyroxine
replacement therapy on NAFLD are lacking. Objectives: to examine the association between overt
hypothyroidism and NAFLD, and to test the effect of levothyroxine (LT4) replacement therapy on
NAFLD among subjects with overt hypothyroidism. Methods: 325 recently diagnosed overt
hypothyroidism subjects were compared to 325 age, sex, and BMI matched subjects regarding metabolic
characteristics, serum liver enzymes, and ultrasound diagnosed NAFLD. The same comparison was
performed on subjects with NAFLD in the case group before and after 12 months of LT4 replacement
therapy. Results: The mean age of participants was $45.22 \pm 5.04$ years old, and 369 (56.8) were females.
Subjects with overt hypothyroidism had a significantly higher prevalence of NAFLD [146 (44.9) versus
83 (25.5), p < 0.001], and higher means of metabolic variables, liver enzymes, and ultrasound liver
measurements (p < 0.5). At 12 months of LT4 therapy, there was $35.6 \%$ reduction in the prevalence of
NAFLD (p<0.001), and significantly reduced values of metabolic variables, and serum liver enzymes
(p < 0.05) among subjects with NAFLD in the case group. Conclusions: Overt hypothyroidism was
significantly associated with NAFLD. Moreover, 12 months LT4 replacement therapy significantly
reduced the prevalence of NAFLD.

Keywords: Levothyroxine Replacement, Non-alcoholic Fatty Liver Disease, Overt Hypothyroidism

Introduction:

When the liver becomes a site for fat accumulation, a cascade of clinical consequences will arise, collectively are referred to as non-alcoholic fatty liver disease (NAFLD). ${ }^{(1)}$ Its clinical entities ranges from fatty liver disease to non-alcoholic steatohepatitis (NASH), where persistent inflammation may proceed to liver cirrhosis with the consequence of a greater risk of hepatocellular carcinoma, and increased demand for liver transplantation. ${ }^{(2)}$

NAFLD is considered the commonest chronic liver disease, with a world-wide prevalence estimated at $20 \%$ to $30 \%$. (3) Its prevalence is rapidly increasing e.g. the prevalence in the United States has been increasing from $18 \%$ in $1988-1991$, to $31 \%$ in 2017. ${ }^{(4)}$

The rapidly increasing prevalence of NAFLD is parallel to the universal upsurge in the prevalence of the features of metabolic syndrome; central adiposity, hyperlipidemia, glucose intolerance/diabetes type 2, and arterial hypertension. ${ }^{(5)}$ Primary NAFLD may precede, coexist, or follow metabolic syndrome, however, several factors have been identified to produce secondary NAFLD including viral infections, steatogenic drugs and alcohol consumption. $^{(6)}$

*Corresponding author: mokhtarshatla@gmail.com

(c) This article is an open access article distributed under the terms and conditions of the Creative Commons Attribution (CC BY) license (http://creativecommons.org/licenses/by/4.0/) 
NAFLD secondary to thyroid diseases; subclinical and overt hypothyroidism, has been recently the focus of much research based on the fact that thyroid hormones are significantly incorporated in the regulation of body fat distribution, energy expenditure, and carbohydrate and lipid metabolism. ${ }^{(7)}$ Additionally, it is widely accepted that conditions causing disturbed serum concentrations of thyroid hormones may predispose to metabolic syndrome, (5) thus correlation to NAFLD. ${ }^{\left({ }^{8}\right)}$

While the global burden of NAFLD is elucidated, there is no specific pharmacologic treatment, and therapies to improve NAFLD still investigational. ${ }^{(9)}$ The increasing evidence of the association between hypothyroidism and NAFLD has urged scientists to consider hypothyroidism-induced NAFLD as a distinct disease entity with a likely favorable effect on NAFLD on normalizing thyroid hormones. ${ }^{(10)}$

Levothyroxine (LT4) is the standard replacement therapy for hypothyroidism and is associated, through metabolic correction, with a substantial reduction of body weight and serum lipids, ${ }^{(11)}$ therefore, appropriate LT4 supplementation, to treat hypothyroidism, yield benefits on NAFLD was suggested. (12) Apparently, few studies have examined the effect of LT4 replacement, on the course of treatment of hypothyroidism, on the prevalence of NAFLD and liver profile. ${ }^{(12,13)}$ It is though that the increasingly prevalent and troublesome liver disease; NAFLD, is commonly disregarded by endocrinologists. Likewise, hematologists seem to disregard the underlying hypothyroidism in individuals presented with NAFLD. Therefore, the objectives of the present study were to assess the association between hypothyroidism and NAFLD to alert the practicing physicians for the consequences of hypothyroidism on the liver. Moreover, this study was purposed to examine the effect of LT4 on NAFLD, aiming to offer an alternative pharmacologic treatment of NAFLD.

\section{Methods:}

This case control study and quasi experimental trial was conducted during the period from February 2017 to December 2019, and involved subjects attended the internal medicine and family medicine clinics of Umm Al-Qura University Medical Center, Makkah, Saudi Arabia.

Inclusion criteria: Subjects of both sexes, and between the ages 18 to 65 years old.

Exclusion criteria: (1) Subjects with known liver disease including viral hepatitis, (2) history of current or past alcohol consumption of any amount, (3) use of hepatotoxic medicines or herbal remedies, and (4) other diseases incorporated in fatty liver disease ${ }^{\text {(14) }}$

Participants were divided into two groups:

(1) Case group: included subjects with recently diagnosed overt hypothyroidism confirmed with high thyroid stimulating hormone (TSH) above $4.2 \mathrm{mIU} / \mathrm{mL}$, and low free thyroxin (FT4) below 
$0.94 \mathrm{mIU} / \mathrm{mL}),{ }^{(15)}$ and are not on levothyroxine replacement therapy yet; (2) Control group: included subjects age, sex, and BMI matched with the case group, and without thyroid dysfunction confirmed with normal serum levels of TSH, FT4, and free tri-iodothyronine (FT3).

Baseline Variables: Participants' full history including socio-demographics, medical, and medications history was gathered using standardized interview, and findings were documented. Body weight, height and waist circumference were measured. Body mass index (BMI) was calculated by dividing weight by the square of the height. Blood pressure was measured after 10-min seated rest, with cuffsize suitable for participant's arm circumference. The average of three consecutive measurements was obtained to determine the systolic and diastolic blood pressure.

Laboratory investigations: Average of $25 \mathrm{ml}$ of venous blood was obtained from each participant after 10 hours of overnight fasting. Total cholesterol (TC), triglycerides (TG), low density lipoprotein cholesterol (LDL-C), high density lipoprotein cholesterol (HDL-C), fasting blood glucose (FBG), and liver enzymes including alanine aminotransferase (ALT), aspartate aminotransferase (AST), $\gamma$-glutamyl transferase (GGT), alkaline phosphatase (ALP), and total bilirubin were measured using the Beckman LX-20 auto-analyzer (Beckman Coulter, La Brea, CA, USA). Thyroid hormones including TSH, FT4, and FT3 were measured using an Elecsys ${ }^{\circledR} 2010$ Disk \& Rack Analyzers (Roche Diagnostics, 9115 Hague Road, Indianapolis, USA). All measurements were performed according to the manufacturer's instructions. Proper functioning of all laboratory equipment was assured through regular precision controls.

The laboratory reference ranges were as follows:

\begin{tabular}{|l|l|}
\hline Laboratory test & Reference range \\
\hline TSH & $0.27-4.2 \mathrm{mIU} / \mathrm{L}$ \\
\hline FT4 & $0.94-1.72 \mathrm{ng} / \mathrm{dL}$ \\
\hline FT3 & $2.01-4.42 \mathrm{pg} / \mathrm{mL}$ \\
\hline ALT & $9-50 \mathrm{U} / \mathrm{L}$ \\
\hline AST & $15-40 \mathrm{U} / \mathrm{L}$ \\
\hline ALP & $38-126 \mathrm{U} / \mathrm{L}$ \\
\hline GGT & $12-43 \mathrm{U} / \mathrm{L}$ \\
\hline
\end{tabular}

Operational definitions: The diagnosis of overt hypothyroidism necessitated reduced serum free $\mathrm{T} 4<0.94 \mathrm{ng} / \mathrm{dl}$ and elevated $\mathrm{TSH}$ levels $>4.20 \mu \mathrm{U} / \mathrm{ml}$. Eu-thyroid state required normal TSH, FT4, and FT3 levels.

Diabetes mellitus was diagnosed according to American Diabetes Association, 2017. ${ }^{(16)}$

Metabolic syndrome and dyslipidemia were defined according to the final report of the Adult Treatment Panel III. ${ }^{(17)}$

\section{Abdominal Ultrasound Examination: \\ Abdominal ultrasound examinations were performed under standardized conditions by a qualified consultant sonographer using a real-}


time electronic convex type scanner (Toshiba Nemio 20 with $3.75 \mathrm{MHz}$ convex-type transducer). Examinations included assessment of the liver and spleen. The liver was assessed with respect to its size and the presence of hepatic steatosis. The list of parameters to be systematically evaluated included: right liver longitudinal span diameter, liver ultrasonographic echo-pattern, and diffuse hypo- or hyper-reflective echoes), portal vein diameter, splenic longitudinal span, and splenic vein diameter.

\section{Ultra-sound criteria for the diagnosis of} NFLD: Fatty liver (hepatic steatosis) diagnosis grounded on the criteria established by Charatcharoenwitthaya et al., (18) and included: a hyper-echoic appearance of the liver parenchyma with fine, tightly packed echoes and posterior beam attenuation. Hepatomegaly was assessed according to liver diameters reported by Niederau et al. ${ }^{(19)}$ Measuring the longitudinal diameters by longitudinal scans in the mid-clavicular line and midline. Measurement results were interpreted as hepatomegally if right mid-clavicular longitudinal span of the liver $>15.5 \mathrm{~cm}$.

The intervention: Conferring to the guideline for treatment of hypothyroidism subsidized by the American Thyroid Association and the American Association of Clinical Endocrinologists. (20) Patients with overt hypothyroidism were prescribed LT4 supplementation to normalize TSH and FT4
(Euthyrox, $25 \mu \mathrm{g}$ and $50 \mu \mathrm{g}$ per tablet, Merck Serono, Darmstadt, Germany). The initial dose was $50 \mu \mathrm{g} /$ day. It was taken every day morning with water on empty stomach, 30 to 60 minutes before breakfast. ${ }^{(20)}$ Serum TSH and FT4 levels were re-evaluated six weeks later, and accordingly, the LT4 dose was adjusted until a state of euthyroidism (TSH of 0.3-3 mIU/L with a normal serum FT4 level) was achieved, and subsequently the dose of LT4 was maintained.

The average daily LT4 dose was $125 \mu \mathrm{g}$. All involved patients were re-evaluated every 12 weeks. Patient status was updated and recorded at each visit, including any recent medical problems, medications, surgeries, and recognizable alterations in lifestyle (e.g., intense exercise or vegetarian diet). Adherence to LT4 intake was monitored by direct question and counting any unused tablets every visit. All participants received follow-up for 6 months. There was no drop out of the follow up as all of the participants receive their healthcare exclusively at the University medical center.

Study End Points: In the present study, the primary endpoints was the effect of $\mathrm{LT}_{4}$ replacement therapy on the prevalence of NAFLD, the serum liver enzymes ALT, AST, GGT, and ALP, and ultrasound characteristics of the liver. The secondary endpoints were changes in BMI, WC, lipid profile including TC, TG, LDL-C, and HDL-C, and prevalence of metabolic syndrome before and after LT4 therapy. 
Sample Size: A sample size of 322 was calculated using the statistical formula $[n=$ Z2pq/d2], (21) where $\mathrm{n}=$ sample size, $Z=$ confidence interval $(\mathrm{CI}), \mathrm{p}=$ prevalence rate (in $\%), \quad \mathrm{q}=1-\mathrm{p}, \mathrm{d}=$ degree of precision. $\mathrm{A}$ confidence interval of $95 \%$, and degree of precision (margin of error) set at 5\% was used. Prevalence rate of $30 \%$ for NAFLD was used. ${ }^{3 \text {, }}$ 4) The prevalence of hypothyroidism is not precisely known, however, a rate of $5 \%$ was identified in developed countries. (22) Nonetheless, a total of 650 subjects were included in the current study, divided into 325 subjects with overt hypothyroidism, and 325 control subjects.

The study was conducted in accordance with the principles of good clinical practice, and was approved by the medical ethics committee of Umm Al-Qura University. All participants provided written informed consent after explanation of the objectives of the study and being assured of keeping their information confidential.

Data management: Data collected through physical examination, laboratory investigations and ultrasonography were tabulated and analyzed statistically by the SPSS software program, Version 20. Quantitative variables were presented as mean and standard deviation (SDs), while qualitative variables were presented as numbers and percentages. To evaluate the variances on quantitative variables, unpaired $\mathrm{t}$ test was used, while qualitative variables were compared with Pearson's chisquare test. To study the influence of LT4 replacement therapy on subjects with NAFLD in the hypothyroid group, a paired-samples t-test was used. A two-tailed value of $\mathrm{p}<0.05$ was considered significant.

\section{Results:}

A total of 650 participants were involved in this study. The mean age of participants was 45.22 \pm 5.04 years old, and 369 (56.8) were females. Participants were divided into 325 subjects with overt hypothyroidism (case group), and 325 subjects without hypothyroidism (control group). There was 136 (41.8) males in the case group, and 145 (44.6) males in the control group $(\mathrm{p}=0.476)$. Mean age of participants was $44.96 \pm 5.277$ in the case group, and $45.48 \pm 4.79$ in the control group $(\mathrm{p}=$ 0.192).

Table (1) compares the metabolic characteristics of both groups, where subjects in the case group had significantly higher mean values of $\mathrm{WC}(\mathrm{P}=0.005)$, serum TC, TG, HDLC, LDL-C, HbA1c, SBP and DBP (p < 0.001), as well as significantly higher number and percentage of subjects with dyslipidemia $(\mathrm{p}=$ 0.001), hypertension $(\mathrm{p}=<0.001)$, type 2 diabetes mellitus $(\mathrm{p}=0.006)$, and metabolic syndrome $(\mathrm{p}<0.001)$.

Table (2) compares the liver biochemical and ultra-sound characteristics of both groups, where subjects in the case group revealed significantly higher mean values of the liver 
transaminases; ALT, AST, GGT ( $\mathrm{p}<0.001)$, and alkaline phosphatase $(\mathrm{p}=0.031)$. Liver ultrasound revealed significantly higher mean values of the right liver lobe span and portal vein diameter $(\mathrm{p}<0.001)$. Overall prevalence of ultrasound diagnosed NAFLD in all participants was 229 (35.2\%). The prevalence of NAFLD was significantly higher in the case group compared to their controls [146 (44.9) versus 83 (25.5), $\mathrm{p}<0.001)]$.

Table (3) reveals the effect of 12 months of LT4 replacement therapy on subjects with NAFLD in the case group, where there was significant reduction in the mean values of the metabolic variables [BMI, WC, TC, TG, LDL$\mathrm{C}(\mathrm{p}<0.001)$, FBG $(\mathrm{P}=0.012)$, and HbA1c $(\mathrm{p}=$ 0.031)], and non-significant increase in HDL-C $(p=0.187)$. The number and percentage of subjects with dyslipidemia, and those with metabolic syndrome was significantly decreased $(\mathrm{p}<0.001)$.

Moreover, as shown in table 4, the 12 months of LT4 replacement therapy was associated with significant reduction in the mean serum values of the liver enzymes ALT, AST, and GGT ( $\mathrm{p}<$ $0.001)$, but not ALP ( $\mathrm{p}=0.073)$, while liver ultrasound showed significantly reduced mean values of the right liver lobe span, and portal vein diameter $(\mathrm{p}<0.001)$. Apparently, the prevalence of ultrasound diagnosed NAFLD was significantly reduced $(35.6 \% ; \mathrm{p}<0.001)$.

Discussion: The association between hypothyroidism and NAFLD has been the focus of many researches beginning with that by Liangpunsakul and Chalasani in 2003. ${ }^{(23)} \mathrm{Few}$ controversial results have been reported, $(24,25)$ whereas several studies have established the association between hypothyroidism and NAFLD, in concordance with the findings of the current study. ${ }^{(3,26,27)}$

Most recently, Guo et al., in their large metaanalysis involving 26 observational studies, concluded that subjects with NAFLD exhibited significantly higher TSH levels compared to those without NAFLD, and that hypothyroidism was associated with a significantly higher risk of NAFLD. ${ }^{(28)}$

In contrast, no significant association could be identified by Ittermann et al. ${ }^{(29)}$ and Ludwig et al. ${ }^{(30)}$ for TSH. Also, Jaruvongvanich et al., in their large meta-analysis, demonstrated that NAFLD was not associated with subclinical, overt, and unclassified hypothyroidism. ${ }^{(31)}$

The close connection between hypothyroidism and metabolic syndrome is well established, and individuals with overt hypothyroidism often show features of the metabolic syndrome ${ }^{(15)}$ Even more, a mutual link between both was documented (e.g., overweight/obesity) as a feature of metabolic syndrome, may mask the effects of thyroid hormones on the liver, by markedly disturbing glucose and lipid metabolism. ${ }^{(8,10)}$

Moreover, as demonstrated in the current study, hypothyroidism was associated with increased levels of atherogenic dyslipidemia 
(LDL-C, TG) which serve to increase accumulation of fat inside the liver. ${ }^{(32)}$ Data has proposed that atherogenic cholesterols were related to NAFLD either. The mechanism underlying hyperlipidemia in hypothyroidism is reduced hepatic triglyceride lipase and increased fatty acid oxidation, (33) producing increased hepatic inflow of triglycerides inside the liver and the development of NAFLD.

Moreover, a direct regulatory effect of TSH on liver lipid metabolism has been described. Hepatocytes had functional TSH receptor (TSHR) expression, and TSH binding to its receptors on hepatocytes up regulate hepatic cholesterol synthesis, and consequently upsurge cholesterol accumulation in the liver. ${ }^{(34)}$ Further, a role of TSH in regulating TG metabolism was described through stimulating TG buildup in hepatocytes brought by a fat-rich diet in mice. ${ }^{(35)}$

The current study was grounded on overt hypothyroidism and revealed that normalizing the raised TSH, and the low T4 via appropriate LT4 supplement could significantly reduce the prevalence of NAFLD. The findings of this work are parallel to former studies that indicated the role of raised TSH in the progression of NAFLD.

Consistent with the present study, Liu et al., in their post-hoc randomized controlled trial involving 360 patients with significant subclinical hypothyroid, LT4 replacement for 15 months was associated with significant reduction in the serum liver enzyme, and 50\% reduction in the prevalence of ultrasound diagnosed NAFLD $(48.5 \%$ before LT4 replacement, versus $24.2 \%$ after LT4 replacement, $\mathrm{p}=0.041) .^{(12)}$ Impressively, Bruinstroop et al in their recent study on euthyroid subjects with type 2 diabetes and NAFLD, demonstrated that supplementation with low dose LT4 for as short as 4 months was accompanied with a substantial decrease of the intra-hepatic fat content, as measured by magnetic resonance spectroscopy. ${ }^{(36)}$

In addition to the reduced prevalence of NAFLD on LT4 therapy, parallel to the findings of the current study, Chaker et al recognized that replacement therapy with LT4 to treat hypothyroidism was accompanied with a significant decrease in BMI and serum lipids. ${ }^{(15)}$

Several data have indicated that hypothyroidism is associated with higher prevalence of dyslipidemia compared with euthyroid subjects. ${ }^{(32)}$ Dyslipidemia is associated with a higher risk for NAFLD. ${ }^{(33)}$ In the current study, the prevalence of dyslipidemia was as high as $73.3 \%$ among hypothyroid patients who had been diagnosed with NAFLD, which is significantly higher compared with those without NAFLD.

The current study revealed that subjects with overt hypothyroid who received LT4 supplement demonstrated a significant decline in mean TC and TG. Data has proposed that atherogenic cholesterols were related to 
NAFLD. ${ }^{(32,33)}$ Generally, this study suggests that the decreased serum TC and TG levels, via LT4 therapy, might relate to the improvement of NAFLD.

Another interesting outcome of the current study was that hypothyroid patients with NAFLD who received LT4 replacement presented a significant reduction in BMI. An independent consequence of obesity on liver fat is well recognized, $(5,6,15)$ and evidence has established that weight reduction is associated with a substantial improvement in the severity of NAFLD. ${ }^{(15,37)}$ It is likely that LT4 replacement could ease weight reduction by boosting the basal metabolic rate and consequently improving NAFLD.

Further studies are required to explore the exact mechanism underlies the advantages of LT4 replacement on NAFLD in hypothyroid patients.

Conclusions: This study demonstrated a significant association between overt hypothyroidism and the increased prevalence of NAFLD. Moreover, the current study revealed an advantageous effect of LT4 replacement on NAFLD in patients with overt hypothyroidism bringing out a significant decrease in the prevalence of NAFLD and serum liver enzymes. Therefore, based on these results, the importance of detection of NAFLD in patients with thyroid dysfunction is suggested, and treatment of overt hypothyroidism with proper LT4 supplementation may be an effective choice for improving NAFLD. Validation of the clinical values of LT4 supplementation on NAFLD with histological endpoints are needed through double-blind, placebo-controlled trials.

Fund: The research was conducted with no fund.

Conflict of Interest: There was no conflict of interest.

\section{References:}

1. Italian Association for the Study of the L. AISF position paper on nonalcoholic fatty liver disease (NAFLD): Updates and future directions. Dig Liver Dis 2017; 49:471-483.

2. Younossi Z, Tacke F, Arrese M, Chander Sharma B, Mostafa I, Bugianesi E, Wai-Sun Wong V, Yilmaz Y, George J, Fan J, Vos MB. Global Perspectives on Nonalcoholic Fatty Liver Disease and Nonalcoholic Steatohepatitis. Hepatology (Baltimore, Md) 2019; 69:2672-2682.

3. $\mathrm{Xu} \mathrm{C}, \mathrm{Xu} \mathrm{L}, \mathrm{Yu} \mathrm{C}, \mathrm{Miao} \mathrm{M}, \mathrm{Li} \mathrm{Y}$. Association between thyroid function and nonalcoholic fatty liver disease in euthyroid elderly Chinese. Clinical endocrinology 2011; 75:240-246.

4. Le MH, Devaki P, Ha NB, Jun DW, Te HS, Cheung RC, Nguyen MH. Prevalence of non-alcoholic fatty liver disease and risk factors for advanced fibrosis and mortality in the United States. PLoS One 2017; 12:e0173499.

5. Mehran L, Amouzegar A, Azizi F. Thyroid disease and the metabolic syndrome. Curr 
Opin Endocrinol Diabetes Obes 2019; 26:256-265.

6. Angulo P. Nonalcoholic fatty liver disease. N Engl J Med 2002; 346:1221-1231.

7. Michalaki MA, Vagenakis AG, Leonardou AS, Argentou MN, Habeos IG, Makri MG, Psyrogiannis AI, Kalfarentzos FE, Kyriazopoulou VE. Thyroid function in humans with morbid obesity. Thyroid 2006; $16: 73-78$.

8. Lonardo A, Nascimbeni F, Mantovani A, Targher G. Hypertension, diabetes, atherosclerosis and NASH: Cause or consequence? J Hepatol 2018; 68:335-352.

9. European Association for the Study of the L, European Association for the Study of D, European Association for the Study of O. EASL-EASD-EASO Clinical Practice Guidelines for the management of nonalcoholic fatty liver disease. Diabetologia 2016; 59:1121-1140.

10. Lonardo A, Ballestri S, Mantovani A, Nascimbeni F, Lugari S, Targher G. Pathogenesis of hypothyroidism-induced NAFLD: Evidence for a distinct disease entity? Dig Liver Dis 2019; 51:462-470.

11. Zhao M, Liu L, Wang F, Yuan Z, Zhang X, Xu C, Song Y, Guan Q, Gao L, Shan Z, Zhang H, Zhao J. A Worthy Finding: Decrease in Total Cholesterol and LowDensity Lipoprotein Cholesterol in Treated Mild Subclinical Hypothyroidism. Thyroid 2016; 26:1019-1029.
12. Liu L, Yu Y, Zhao M, Zheng D, Zhang X, Guan Q, Xu C, Gao L, Zhao J, Zhang H. Benefits of levothyroxine replacement therapy on nonalcoholic fatty liver disease in subclinical hypothyroidism patients. Int $\mathbf{J}$ Endocrinol 2017; 2017:5753039.

13. Ineck BA, $\mathrm{Ng} \mathrm{TM}$. Effects of subclinical hypothyroidism and its treatment on serum lipids. Ann Pharmacother 2003; 37:725730.

14. Joy D, Thava VR, Scott BB. Diagnosis of fatty liver disease: is biopsy necessary? Eur J Gastroenterol Hepatol 2003; 15:539-543.

15. Chaker L, Bianco AC, Jonklaas J, Peeters RP. Hypothyroidism. Lancet 2017; 390:1550-62.

16. American Diabetes Association. "2. Classification and Diagnosis of Diabetes". Diabetes Care 2017; 40 (1): 1124.

17. Third Report of the National Cholesterol Education Program (NCEP) Expert Panel on Detection, Evaluation, and Treatment of High Blood Cholesterol in Adults (Adult Treatment Panel III) final report. Circulation 2002; 106:3143-3421.

18. Charatcharoenwitthaya P, Lindor KD. Role of radiologic modalities in the management of non-alcoholic steatohepatitis. Clin Liver Dis 2007; 11:37-54.

19. Niederau C, Sonnenberg A, Muller JE, Erckenbrecht JF, Scholten T, Fritsch WP. Sonographic measurements of the normal 
liver, spleen, pancreas, and portal vein. Radiology 1983; 149:537-540.

20. Garber JR, Cobin RH, Gharib H, Hennessey JV, Klein I, Mechanick JI, Pessah-Pollack $\mathrm{R}$, Singer PA, Woeber KA, American Association of Clinical Endocrinologists, American Thyroid Association Taskforce on Hypothyroidism in A. Clinical practice guidelines for hypothyroidism in adults: cosponsored by the American Association of Clinical Endocrinologists and the American Thyroid Association. Endocr Pract 2012; 18:988-1028.

21. Wiegand H. Kish, L.: Survey Sampling. John Wiley \& Sons, Inc., New York, London 1965, IX + 643 S., 31 Abb., 56 Tab., Preis 83 s. Biometrische Zeitschrift 1968;10:88-89.

22. Hollowell JG, Staehling NW, Flanders WD, Hannon WH, Gunter EW, Spencer CA, Braverman LE. Serum TSH, T(4), and thyroid antibodies in the United States population (1988 to 1994): National Health and Nutrition Examination Survey (NHANES III). J Clin Endocrinol Metab 2002; 87:489-499.

23. Liangpunsakul S, Chalasani N. Is hypothyroidism a risk factor for nonalcoholic steatohepatitis? Journal of clinical gastroenterology 2003; 37:340-343.

24. Eshraghian A, Dabbaghmanesh MH, Eshraghian H, Fattahi MR, Omrani GR. Nonalcoholic fatty liver disease in a cluster of Iranian population: thyroid status and metabolic risk factors. Arch Iran Med 2013; 16:584-589.

25. Mazo DF, Lima VM, Stefano JT, Rabelo F, Faintuch J, Oliveira CP. Gluco-lipidic indices in treated hypothyroidism associated with nonalcoholic fatty liver disease. Arquivos de gastroenterologia 2011; 48:186-189.

26. Chung GE, Kim D, Kim W, Yim JY, Park MJ, Kim YJ, Yoon JH, Lee HS. Nonalcoholic fatty liver disease across the spectrum of hypothyroidism. J Hepatol 2012; 57:150-6. 27. Xu L, Ma H, Miao M, Li Y. Impact of subclinical hypothyroidism on the development of non-alcoholic fatty liver disease: a prospective case-control study. J Hepatol 2012; 57:1153-1154.

27. Guo Z, Li M, Han B, Qi X. Association of non-alcoholic fatty liver disease with thyroid function: A systematic review and meta-analysis. Dig Liver Dis 2018; 50:115362. 29.

28. Ittermann T, Haring R, Wallaschofski H, Baumeister SE, Nauck M, Dörr M, Lerch MM, Meyer zu Schwabedissen HE, Rosskopf D, Völzke H. Inverse association between serum free thyroxine levels and hepatic steatosis: results from the Study of Health in Pomerania. Thyroid: official journal of the American Thyroid Association 2012; 22:568-74. 
29. Ludwig U, Holzner D, Denzer C, Greinert A, Haenle MM, Oeztuerk S, Koenig W, Boehm BO, Mason RA, Kratzer W, Graeter $\mathrm{T}$, the E-S. Subclinical and clinical hypothyroidism and non-alcoholic fatty liver disease: a cross-sectional study of a random population sample aged 18 to 65 years. BMC Endocrine Disorders 2015; $15: 41$.

30. Jaruvongvanich V, Sanguankeo A, Upala S. Nonalcoholic Fatty Liver Disease Is Not Associated with Thyroid Hormone Levels and Hypothyroidism: A Systematic Review and Meta-Analysis. Eur Thyroid J 2017; 6:208-215.

31. Danford CJ, Lai M. NAFLD: a multisystem disease that requires a multidisciplinary approach. Frontline Gastroenterol 2019; 10:328-329.

32. Park HT, Cho GJ, Ahn KH, Shin JH, Hong SC, Kim T, Hur JY, Kim YT, Lee KW, Kim SH. Thyroid stimulating hormone is associated with metabolic syndrome in euthyroid postmenopausal women. Maturitas 2009; 62:301-305.

33. Tian L, Song Y, Xing M, Zhang W, Ning G, Li X, Yu C, Qin C, Liu J, Tian X, Sun X, Fu R, Zhang L, Zhang X, Lu Y, Zou J, Wang L, Guan Q, Gao L, Zhao J. A novel role for thyroid-stimulating hormone: up-regulation of hepatic 3-hydroxy-3-methyl-glutarylcoenzyme A reductase expression through the cyclic adenosine monophosphate/protein kinase $\mathrm{A} /$ cyclic adenosine monophosphateresponsive element binding protein pathway. Hepatology (Baltimore, Md) 2010; 52:c1401-1409.

34. Yan F, Wang Q, Lu M, Chen W, Song Y, Jing F, Guan Y, Wang L, Lin Y, Bo T, Zhang J, Wang T, Xin W, Yu C, Guan Q, Zhou X, Gao L, Xu C, Zhao J. Thyrotropin increases hepatic triglyceride content through upregulation of SREBP-1c activity. J Hepatol 2014; 61:1358-1364.

35. Bruinstroop E, Dalan R, Cao Y, Bee YM, Chandran K, Cho LW, Soh SB, Teo EK, Toh SA, Leow MKS, Sinha RA, Sadananthan SA, Michael N, Stapleton HM, Leung C, Angus PW, Patel SK, Burrell LM, Lim SC, Sum CF, Velan SS, Yen PM. Low-Dose Levothyroxine Reduces Intrahepatic Lipid Content in Patients With Type 2 Diabetes Mellitus and NAFLD. J Clin Endocrinol Metab 2018; 103:2698-2706.

36. Wong VW, Chan RS, Wong GL, Cheung BH, Chu WC, Yeung DK, Chim AM, Lai JW, Li LS, Sea MM, Chan FK, Sung JJ, Woo J, Chan HL. Community-based lifestyle modification program for nonalcoholic fatty liver disease: a randomized controlled trial. J Hepatol 2013; 59:536-542. 
Table (1): Metabolic Characteristics of Subjects with Overt Hypothyroidism and their Controls

\begin{tabular}{|c|c|c|c|}
\hline Variable & $\begin{array}{c}\text { Hypothyroidism } \\
(\mathbf{N}=325)\end{array}$ & $\begin{array}{l}\text { Controls } \\
(\mathrm{N}=325)\end{array}$ & P-value \\
\hline - $\mathrm{WC}(\mathrm{cm})$ & $93.02 \pm 5.87$ & $91.78 \pm 5.22$ & 0.005 \\
\hline - $\quad \mathrm{TC}(\mathrm{mg} / \mathrm{dL})$ & $219.24 \pm 26.85$ & $195.46 \pm 17.67$ & $<0.001$ \\
\hline - $\quad \mathrm{TG}(\mathrm{mg} / \mathrm{dL})$ & $165.93 \pm 35.87$ & $112.36 \pm 26.19$ & $<0.001$ \\
\hline - $\quad$ HDL-C $(\mathrm{mg} / \mathrm{dL})$ & $42.22 \pm 5.67$ & $43.64 \pm 7.96$ & $<0.001$ \\
\hline - $\quad$ LDL-C $(\mathrm{mg} / \mathrm{dL})$ & $128.97 \pm 15.77$ & $116.68 \pm 23.99$ & $<0.001$ \\
\hline - Dyslipidemia [N (\%)] & $218(67)$ & $112(34.5)$ & $<0.001$ \\
\hline - $\mathrm{FBG}(\mathrm{mg} / \mathrm{dL})$ & $114.86 \pm 18.4$ & 107.5715 .36 & $<0.001$ \\
\hline - $\operatorname{HBA1C}(\%)$ & $6.18 \pm 0.8$ & $5.73 \pm 0.86$ & $<0.001$ \\
\hline - $\mathrm{DM} 2[\mathrm{~N}(\%)]$ & $73(22.5)$ & $46(14.5)$ & 0.006 \\
\hline - Hypertension [N (\%)] & $79(24.3)$ & $53(16.3)$ & $<0.001$ \\
\hline - $\mathrm{SBP}(\mathrm{mm} \mathrm{Hg})$ & $135.57 \pm 10.52$ & $127.84 \pm 12.16$ & $<0.001$ \\
\hline - $\quad \mathrm{DBP}(\mathrm{mm} \mathrm{Hg})$ & $83.46 \pm 8.04$ & $79.49 \pm 6.9$ & $<0.001$ \\
\hline - $\quad$ Metabolic syndrome $[\mathrm{N}(\%)]$ & $159(48.9)$ & $96(29.5)$ & $<0.001$ \\
\hline
\end{tabular}

There were significantly higher values of metabolic variables among subjects with overt hypothyroid $(\mathrm{p}<0.05)$. 
Table 2. Liver Biochemical and Ultrasound Characteristics of Subjects with Overt Hypothyroidism and their Controls

\begin{tabular}{|c|c|c|c|}
\hline Variable & $\begin{array}{l}\text { Hypothyroidism } \\
(\mathbf{N}=325)\end{array}$ & $\begin{array}{l}\text { Controls } \\
(\mathrm{N}=325)\end{array}$ & P-value \\
\hline \multicolumn{4}{|c|}{ Liver enzymes: } \\
\hline - $\quad$ ALT (IU/L) & $44.13 \pm 17.97$ & $19.89 \pm 6.11$ & $<0.001$ \\
\hline - $\quad \operatorname{AST}(\mathrm{IU} / \mathrm{L})$ & $41.03 \pm 7.82$ & $20.73 \pm 6.33$ & $<0.001$ \\
\hline - GTT (IU/L) & $43.85 \pm 16.58$ & $35.59 \pm 20$ & $<0.001$ \\
\hline $\begin{array}{l}\text { Alkaline phosphatase } \\
\text { (IU/L) }\end{array}$ & $71.66 \pm 14.02$ & $68 \pm 12.64$ & 0.031 \\
\hline \multicolumn{4}{|c|}{ Liver ultrasound: } \\
\hline $\begin{array}{l}\text { Right liver lobe span } \\
(\mathrm{cm})\end{array}$ & $14.66 \pm 2.48$ & $12.5 \pm 1.1$ & $<0.001$ \\
\hline $\begin{array}{l}\text { Portal vein diameter } \\
(\mathrm{cm})\end{array}$ & $12.5 \pm 1.1$ & $10.18 \pm 1.05$ & $<0.001$ \\
\hline $\begin{array}{l}\text { Ultrasound-diagnosed } \\
\text { NAFLD }[\mathrm{N}(\%)]\end{array}$ & $146(44.9)$ & $83(25.5)$ & $<0.001$ \\
\hline
\end{tabular}

There were significantly higher values of serum liver enzymes, and ultrasound liver measurements ( $\mathrm{p}<0.05)$, as well as significantly higher prevalence of NAFLD among subjects with overt hypothyroid compared to their controls [(146 (44.9) versus 83 (25.5); $\mathrm{p}<0.001)$ ]. 
Table (3): Metabolic Characteristics of Subjects with NAFLD in the Overt Hypothyroid Group, Before and After Levothyroxine Replacement Therapy

\begin{tabular}{|c|c|c|c|c|}
\hline \multirow[t]{2}{*}{ Variable } & \multicolumn{2}{|c|}{$\begin{array}{l}\text { NAFLD } \\
(N=146)\end{array}$} & \multirow[t]{2}{*}{ Mean } & \multirow[t]{2}{*}{ P-value } \\
\hline & $\begin{array}{c}\text { Before } \\
\text { LT4 therapy }\end{array}$ & $\begin{array}{c}\text { After } \\
\text { LT4 therapy }\end{array}$ & & \\
\hline - $\mathrm{BMI}$ & $30.17 \pm 2.08$ & $28.02 \pm 2.21$ & $-2.15 \pm 2.26$ & $<0.001$ \\
\hline - $\quad \mathrm{WC}(\mathrm{cm})$ & $96.83 \pm 5.19$ & $91.45 \pm 3.05$ & $-5.37 \pm 4.13$ & $<0.001$ \\
\hline - $\mathrm{TC}(\mathrm{mg} / \mathrm{dL})$ & $236.63 \pm 20.68$ & $218.39 \pm 17.4$ & $-18.24 \pm 23.49$ & $<0.001$ \\
\hline - $\mathrm{TG}(\mathrm{mg} / \mathrm{dL})$ & $190.75 \pm 40.04$ & $142.89 \pm 28.66$ & $-47.86 \pm 45.75$ & $<0.001$ \\
\hline - $\mathrm{HDL}-\mathrm{C}(\mathrm{mg} / \mathrm{dL})$ & $42.22 \pm 5.67$ & $43.04 \pm 6.12$ & $+0.616 \pm 5.62$ & 0.187 \\
\hline - $\quad \mathrm{LDL}-\mathrm{C}(\mathrm{mg} / \mathrm{dL})$ & $135.36 \pm 15.14$ & $129.35 \pm 13.78$ & $-6.0 \pm 20.01$ & $<0.001$ \\
\hline 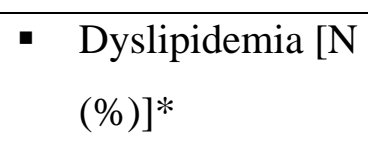 & $107(73.3)$ & $78(53.4)$ & - & $<0.001$ \\
\hline - $\quad \mathrm{FBG}(\mathrm{mg} / \mathrm{dL})$ & $124.64 \pm 17.77$ & $119.41 \pm 17.68$ & $-5.22 \pm$ & 0.012 \\
\hline - $\quad \mathrm{HBA} 1 \mathrm{C}(\%)$ & $6.43 \pm .76$ & $6.3 \pm 0.527$ & $-0.135 \pm 0.75$ & 0.031 \\
\hline 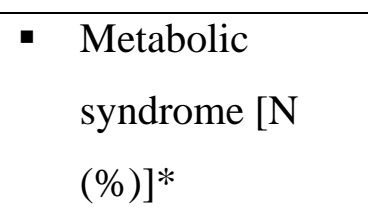 & $98(67.1)$ & $69(48.5)$ & - & $<0.001$ \\
\hline
\end{tabular}

*Chi square test.

There was significant statistical reduction in the values of metabolic variables $(\mathrm{p}<0.05)$. There was no significant statistical difference as regard HDL-C $(\mathrm{p}=0.187)$. 
Table (4): Liver Biochemical and Ultrasound Characteristics of Subjects with NAFLD in the Overt Hypothyroid Group, Before and After Levothyroxine Replacement Therapy

\begin{tabular}{|c|c|c|c|c|}
\hline \multirow[t]{2}{*}{ Variable } & \multicolumn{2}{|c|}{$\begin{array}{l}\text { NAFLD } \\
(N=146)\end{array}$} & \multirow[t]{2}{*}{ Mean } & \multirow[t]{2}{*}{ P-value } \\
\hline & $\begin{array}{c}\text { Before } \\
\text { LT4 } \\
\text { therapy }\end{array}$ & $\begin{array}{c}\text { After } \\
\text { LT4 therapy }\end{array}$ & & \\
\hline \multicolumn{5}{|l|}{ Liver enzymes: } \\
\hline - $\quad$ ALT (IU/L) & $\begin{array}{c}49.66 \pm 17 \\
87\end{array}$ & $38.47 \pm 3.98$ & $-11.19 \pm 17.54$ & $<0.001$ \\
\hline - $\operatorname{AST}(\mathrm{IU} / \mathrm{L})$ & $\begin{array}{c}42.29 \pm 7.6 \\
9\end{array}$ & $34.47 \pm 13.13$ & $-7.815 \pm 11.86$ & $<0.001$ \\
\hline - GTT (IU/L) & $\begin{array}{c}49.21 \pm 17 . \\
74\end{array}$ & $40.86 \pm 17.95$ & $-8.349 \pm 13.94$ & $<0.001$ \\
\hline - $\quad$ ALP (IU/L) & $\begin{array}{c}75.68 \pm 13 . \\
58\end{array}$ & $73.47 \pm 10.85$ & $-2.21 \pm 14.99$ & 0.073 \\
\hline \multicolumn{5}{|l|}{ Liver ultrasound: } \\
\hline - $\quad$ Right liver lobe span $(\mathrm{cm})$ & $\begin{array}{c}17.06 \pm 1.0 \\
7\end{array}$ & $15.9 \pm 2.19$ & $-1.157 \pm 2.03$ & $<0.001$ \\
\hline - Portal vein diameter $(\mathrm{cm})$ & $11.07 \pm 0.9$ & $10.15 \pm 1.11$ & $-0.919 \pm 1.12$ & $<0.001$ \\
\hline $\begin{array}{l}\text { Ultrasound diagnosed } \\
\text { NAFLD }[\mathrm{N}(\%)]^{*}\end{array}$ & $146(100)$ & $94(64.4)$ & - & $<0.001$ \\
\hline
\end{tabular}

Levothyroxine replacement therapy was associated with a significant reduction $(35.6 \%, \mathrm{p}<0.001)$ in the prevalence of NAFLD, and mean values of serum liver enzymes ALT, AST, and GGT, and ultrasound liver measurements $(\mathrm{p}<0.001)$. 
قصور الغدة الارقية و الكبد الدهنى غير الكحولى: الصلّة العي تأثير العلاج التعويضى بالليفوثيروكسين

مختار محفوظ شتلة ـ أحمد سلمان فيصل

الخلفية: الصلة بين قصور الغدة الدرقية و الكبد الدهنى غير الكحولى مجالا" مثزايدا" للار اسة مع نتائج منضاربة و الدراسات حول تأثير العلاج التعويضى بالليفوثيروكسين مفتقرة. الأهداف: تهدف هذه الدراسة إلى دراسة الصلة بين قصور الغدة الدرقية العلنى و الكبد الدهنى غير الكحولى و إختبار تأثير العلاج التعويضى بالليفوثيروكسين على الكبد الدهنى غير الكحولى. المنهجية وطرق البحث: شملت الدر اسة 325 مريض قصور الغدة الدرقية العلنى حديث التتخيص مقارنة بعدد منطابق من مجمو عة ضابطة مطابقين فى السن و النوع لئى

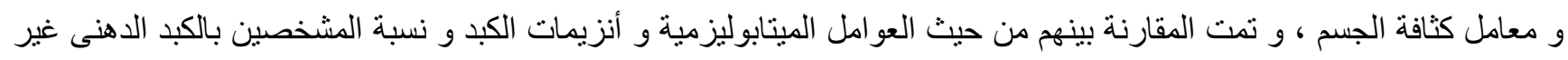
الكحولى بالموجات الصوتية. و تكررت المقارنة على المشاركين المشخصين بالكبد الدهنى و قصور الغدة الدرقية بعد 12 شهر ا من

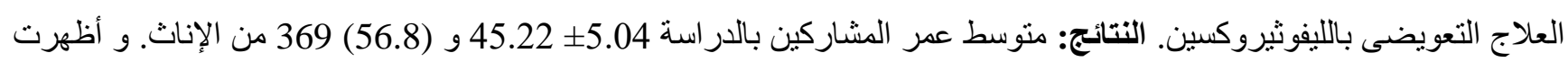
النتائج أن المشاركين فى مجمو عة ذوى قصور الغدة الدرقية أعلى بشكل إحصائى ذو مغزى من حيث معدل الشخصين بالكبد الدهنى غير الكحولى (44.9\% مقابل 25.5\%) و العو امل الميتابوليزمية ومستويات أنزيمات الكبد مقارنة بالمشاركين من المجمو عة الضابطة.

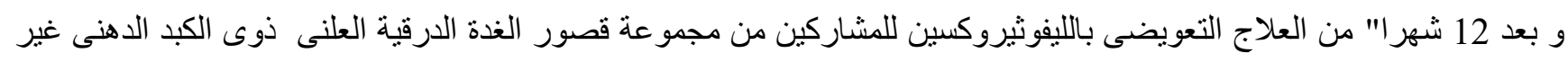

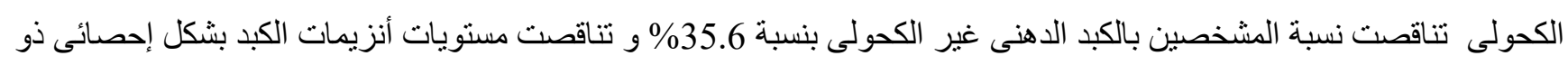
مغزى. الخلاصة: تخلص هذة الدر اسة على وجود علاقة ذات مغزى بين قصور الغدة الدرقية العلنى و الكبد الدهنى غير الكحولى. كما تخلص على أن 12 شهر ا" من العلاج التعويضى بالليفوثيروكسين قلل بشكل ملحوظ نسبة المشخصين بالكبد الدهنى غير الكحولى. 